\title{
COMPARATIVE ANALYSIS OF NDVI INDEX AND DIFFERENT SATELLITE IMAGES CLASSIFICATIONS IN DETERMINATION THE VEGETATION INVENTORY OF VRČIN SETTLEMENT
}

\author{
Nemanja Vagić*1 \\ *University of Belgrade - Faculty of Geography, Belgrade
}

\begin{abstract}
The modern way of life has affected the extremely high level of environmental degradation. Modern technologies, on the one hand, degrade our environment, but on the other they can also be used to preserve and improve its quality. An efficient monitoring system is able to monitor the status and changes in the vegetation cover of a particular area. In this paper will be shown the determination of the vegetation inventory of the settlement Vrčin through the NDVI (Normalized Difference Vegetation Index) and comparison of the data thus obtained with the various available classifications of satellite images, in order to determine the best monitoring system in the environment through remote detection.
\end{abstract}

Keywords: NDVI, vegetation cover, environmental protection, land cover, remote sensing, GIS.

\section{Introduction}

Modern world trends bring a huge risk of degradation of environment in which people live. The trail that leaves human civilization is heavier than the traces of all other species together, because humans have transformed about half of the planet (Ракић, 2006). The development of culture, science and technology had influence on development of society at the expense of conquering

1 Corresponding author: N. Vagić, University of Belgrade - Faculty of Geography, Belgrade; e-mail: vagic@live.com 
nature (Милинчић et al., 2013). The continuation of such tendencies is completely unsustainable, and it is necessary to make a balance between economic progress from one side and requirements of environment on the other (Šabić et al., 2013). In order to stop the devastation of the environment and at some point to start improving its quality, it is necessary to establish quality monitoring. Environmental monitoring is carried out by scientific experts of various profiles (chemists, physicists, geographers, biologists, meteorologists) in both national and international projects (Belić et al., 2012). The most efficient way of monitoring is through remote sensing, which can also record positive (progression) changes in the environment (rehabilitation, recultivation, revitalization) and negative (different types of degradation) (Томић, 2014). Control and management of the environment prevents it from entering the degradation phase, thus eliminating potential investments in its rehabilitation (Љешевић, 2005).

Anthropogenic factors in the environment imply the effects of human activities on habitat changes (Šabić et al., 2018), and they can be manifested through changes in land use, degradation of forests and agricultural areas (the erosion occurrence), as well as through more intensive development of certain species and redistribution of other types of vegetation, etc (Milincic et al., 2013). This impact is the strongest in urban environment that represents a complex mosaic of autochthonous coverings (geological, pedological, hydrological, vegetation, etc.) modified by anthropogenic impact on land use (Đurđić et al., 2011).

Determination of vegetation cover is therefore of high importance for planning of a certain space, as well as for scientific research work, especially in multicriteria decision making, because a large number of spatial analyzes of suitability for different purposes as one of the criteria often distinguishes the type and distribution of vegetation. For both purposes, it can rely on existing supervised and unsupervised classifications of satellite images that are relatively recent and publicly available to users around the world.

Also, assuming that all these global or at least continental databases can not be completely accurate, because in one base it is almost impossible to integrate thousands of satellite images created at different times and under different climatic conditions, it is also possible to approach the independent determination of the vegetation cover of the certain space. To do this as accurately as possible, the most effective methodology is to process satellite images through the NDVI, and the classification of the obtained results into the corresponding vegetation classes is best done by using the natural but also false color composites of the satellite image, through which the boundaries between close types of vegetation cover can be clearly defined.

By transitioning to new technologies spatial data most often have a digital form (Борисов et al., 2009). Geographic information systems support the decision-making process by providing a flexible environment for analyzing dif- 
ferent alternatives based on their criteria (Смиљанић \& Ђурђић, 2006). So far, various analyzes have been made to compare the NDVI with the databases on land use (Jovanović et al., 2018; Guo et al., 2017; Ma et al., 2017; Zhang et al., 2015; Kovalskyy et al., 2012 Peng et al., 2011; Wardlow \& Egbert, 2010; Bedard et al., 2006; Yague \& Garcia, 2004). In this paper will be presented the review of the publicly-available classifications of satellite images and their comparative analysis with independent classification through the NDVI for the surface of Vrčin settlement, in order to determine their similarities, differences and the mutual degree of deviation in share and distribution of corresponding vegetation classes.

\section{Basic information abouth the settlement}

Vrčin is one of 15 settlements located in the territory of the municipality of Grocka, and it is its largest settlement with an area of $49.1 \mathrm{~km}^{2}$, which represents $17 \%$ of the area of this municipality. It is located in the western part of the municipality, $20 \mathrm{~km}$ southeast of Belgrade (Figure 1), at $44^{\circ} 40^{\prime}$ south and $20^{\circ} 36^{\prime}$ east, and the average altitude of this site is $200 \mathrm{~m}$. In the north it borders settlements Leštane and Boleč, in the east settlements Zaklopača and Grocka, which is also a municipal center, in the southeast settlement Begaljica, in the south, southwest and west settlement Ripanj and in the northwest settlement Zuce. It was recorded in the 2011 census that Vrčin has a total of 9,088 inhabitants.

\section{Research methodology}

The vegetation cover of a certain area itself is very complex and during its analysis it is necessary to determine the appropriate methodology that will be as precise as possible, more economical and less demanding in terms of time.

Taking into account all factors that occur on that occasion, the obtained research methodology is divided into the following phases:

- Phase 1. Setting the goal of research and defining tasks;

- Phase 2. Analysis of collected data;

- Phase 3. Synthesis of the results obtained;

- Phase 4. Comparison of different methodologies;

- Phase 5. Displaying their mutual compatibility and diversity.

2 Упоредни преглед броја становника 1948-2011. 


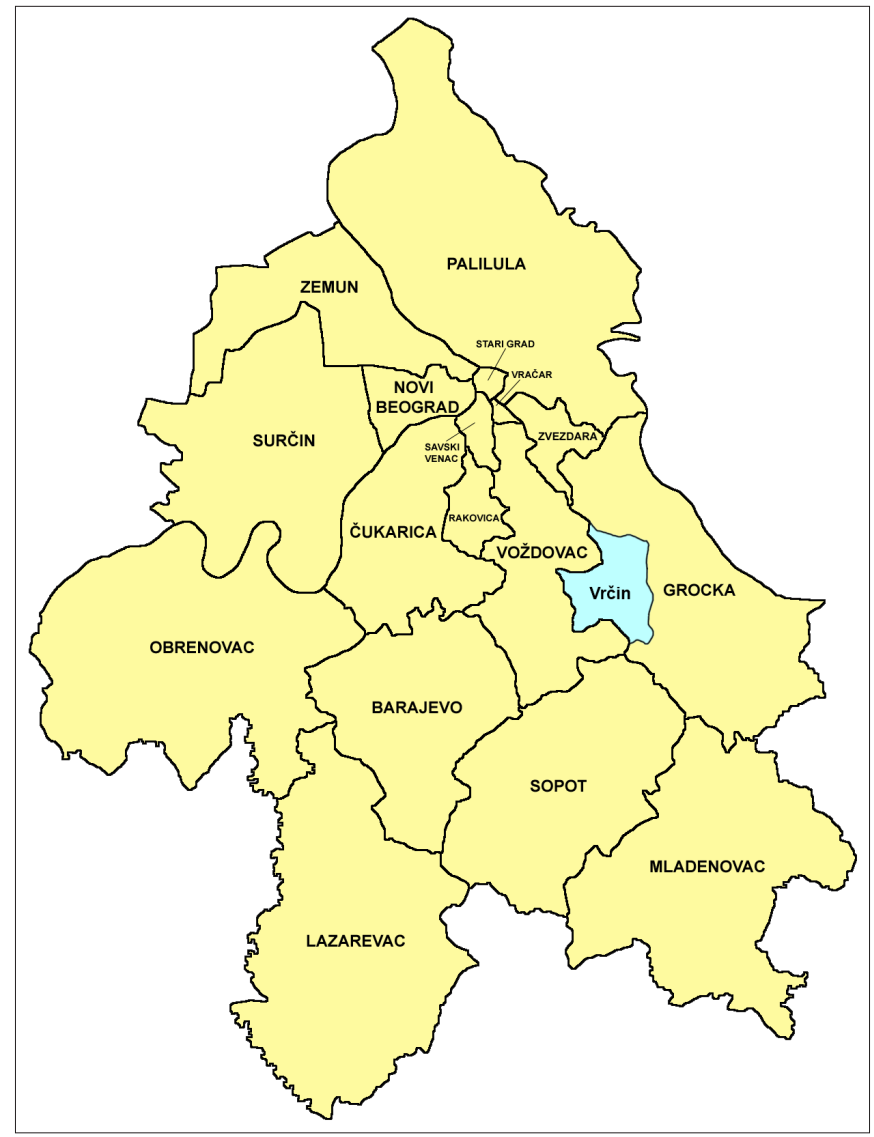

Figure 1. Location of the Vrčin settlement in the City of Belgrade

The goal of this analysis is to create map of vegetation types in the area of settlement Vrčin and to obtain appropriate quantitative data, as well as to compare the obtained results with the existing results obtained by using other methodologies.

The tasks that are based on this include the collection of the necessary data, which implies satellite images of this area and their adequate processing, through which the detailed research results will be obtained through a detailed analysis. One of the most important benefits of using satellite images is that through use in teledetecting they represent an abundance of information for the creation of an ecological information system of the environment (Милановић \& Љешевић, 2009).

For the purposes of analysing the vegetation cover of settlement Vrčin through the NDVI, the image obtained from the Landsat 5 satellite was used, 
with the mark LT51860292011232MOR00 and the resolution of 30*30 m (NASA \& USGS, 2011). The image is processed in the GIS software IDRISI, which is primarily used for this purpose. The image is reduced to dimensions slightly beyond the boundaries of the settlement, since the analysis of this area does not require a complete image.

The NDVI is used for monitoring, analyzing and mapping time and spatial characteristics of physiological and biophysical vegetation characteristics, and is directly related to soil parameters because soil quality directly affects the health of plants (Бадњаревић и др., 2012). NDVI is a relatively cheap and quick, provide a lot of essential information, it is easy to be implemented and has a high level of scientific objectivity (Jovanović \& Milanović, 2015).

On the other hand, the most well-known and most commonly used classification of land use in Serbia is CORINE (Coordination of Information on the Environment). Corine Land Cover methodology defines the nomenclature and definition of the land cover classes, as well as the manner of their mapping. In practical terms, this database implies the mapping of previously defined land cover classes (Несторов \& Протић, 2009).

Apart from the Corine database there are many others with a higher or lower degree of data quality. For the purposes of comparison with the results of the NDVI for Vrčin settlement, in addition to the CORINE database, GlobeLand30, GlobCover, MODIS, Global Land Cover Characterization and Global Land Survey were also used in this paper.

GlobeLand30 contains data sets which are important for monitoring environmental changes and resource management at global, regional and local levels (Wulder \& Coops, 2014). For this database, it took more than 20 thousand Landsat Chinese HJ-1 satellite images to cover the entire Earth at resolution of $30 \mathrm{~m}$ (Jun et al, 2014), and the achieved accuracy of the classification is $80 \%$ (NGCC, 2014).

Within the Climate Change Initiative (CCI) of the European Space Agency, the CCI Land Cover partnership has released GlobCover, the official version of the 300m global land cover for each year in the period from 1992 to 2015. Depending on area surface, it is stated that this database reaches an accuracy of $73 \%$ for 23 classes of land use (ESA, 2010a).

MODIS maps with a resolution of 500 meters (17 land use classes) describe dominant classes based on a ten-year period (2001-2010). Research has shown a year over year variability of $40 \%$ of pixels that show changes in the class one or more times in the range of 10 years (GIS Geography, n.d.). Each pixel on the map was created in relation to the highest total representation from 2001 to 2010 (Broxton et al., 2014). The data is redistributed to the GRID cells, obtained from 
the MODIS ${ }^{3}$ sinusoidal network on the classic latitude - longitude network, and the map size is $43200 * 86400$ pixels, corresponding to a resolution of 15 arcseconds (LCI, 2010).

The National Center for Earth Resources Observation and Science (EROS) of the U.S. Geological Survey (USGS), University of Nebraska-Lincoln and the European Commission's Joint Research Center have created Global Land Cover Characterization (GLCC), the global database of land cover with a resolution of $1 \mathrm{~km}$ for application in a wide range of environmental research and modeling (Loveland et al, 2000). GLCC is based on the Advanced Very High Resolution Radiometer (AVHRR) using a unsupervised approach to classifying images (USGS, n.d.a). In relation to the land surface, the GLCC ${ }^{4}$ reaches an accuracy of $66.9 \%$ (GIS Geography, n.d.).

Global Land Survey (GLS) datasets have been created through the collaboration of NASA and the United States Geological Survey (USGS), and they are designed to enable scientists and data users to access consistent and as precise datasets as possible (NASA \& USGS, n.d.). Research has shown that the overall accuracy of the GLS database is about $91 \%$ in terms of forest cover, while the accuracy of the map of forest changes decreases to $88 \%$ (GIS Geography, n.d.).

\section{Research results}

NDVI

For the classification of the NDVI, it is necessary to produce different color composites. Various combinations of spectral channels obtained a true color composite (Figure 3-1), used to separate parts of the terrain without vegetation, as well as for the selection of different vegetation types, as well as fake color composites for analysis of low vegetation (Figure 3-2), for analysis of high vegetation (Figure 3-3) and for the analysis of agricultural land (Figure 3-4). For each of the analyzes above, along with true and false color composites, the NDVI (Figure 3-5) was used, on the basis of which the vegetation is classified into the appropriate classes.

The values of the NDVI are classified in the software, and the map of types and vegetation layout is obtained based on the chosen criterion (Figure 3-6), and on the other hand, the data on the surfaces of each of the selected classes are obtained individually (Table 1).

\footnotetext{
3 LCI (2010)

4 USGS (n.d.b)
} 
Comparative Analysis of NDVI Index and Different Satellite Images Classifications in Determination the Vegetation Inventory of Vrčin Settlement

Table 1. Types of vegetation according to NDVI

\begin{tabular}{|c|r|r|}
\hline Type of vegetation & Surface area $\mathbf{( k m}^{\mathbf{2}}$ & \multicolumn{1}{|c|}{ Share $\mathbf{( \% )}$} \\
\hline Areas without vegetation & 1.34 & 2.72 \\
\hline Agricultural areas & 5.85 & 11.91 \\
\hline Meadows and pastures & 11.00 & 22.39 \\
\hline Shrubs & 14.20 & 28.90 \\
\hline Deciduous forests & 16.44 & 33.47 \\
\hline Mixed forests & 0.30 & 0.61 \\
\hline In total & $\mathbf{4 9 . 1 2}$ & $\mathbf{1 0 0 . 0 0}$ \\
\hline
\end{tabular}

According to the data, the most common type of vegetation in the studied area is the deciduous forests with slightly more than a third of the analyzed area, and they are most widespread in the eastern, northeastern and western parts of the settlement. They are followed by shrubs, which mostly are present on the perimeter of deciduous forests, and then meadows and pastures that are present on the entire surface of the settlement. Arabled agricultural land is mostly noticiable in the central, northern part and along the perimeter of the western border of the settlement. The smallest share in the settlement occupy areas without vegetation. They are located along the highway E75, which passes through the settlement in the direction northwest-southeast, in industrial zones on both sides of this road and in the center of the settlement, which represents the most populated part of this area.

\section{Classifications of satellite images}

\section{CORINE}

This paper presents the classification of the vegetation cover of Vrčin settlement according to the Corine database for 2000 and 2012. On the basis of the Corine $2000^{5}$ database, the map of vegetation and land use was prepared (Figure 3-7), where the areas occupied by different types of vegetation according to this methodology were calculated (Table 2).

\footnotetext{
5 Copernicus $(2000)$
} 
Table 2. Types of vegetation according to the Corine2000 database

\begin{tabular}{|c|r|r|}
\hline Land use and types of vegetation & Surface area $\left.\mathbf{( k m}^{\mathbf{2}}\right)$ & Share (\%) \\
\hline Discontinuous urban fabric & 6.81 & 13.87 \\
\hline Non-irrigated arable land & 3.37 & 6.86 \\
\hline Fruit trees and berry plantations & 0.0006 & 0.0012 \\
\hline Pastures & 0.12 & 0.25 \\
\hline Complex cultivation patterns & 13.33 & 27.13 \\
\hline $\begin{array}{c}\text { Land principally occupied by agriculture, } \\
\text { with significant areas of natural vegetation }\end{array}$ & 21.22 & 43.19 \\
\hline Broad-leaved forests & 3.36 & 6.84 \\
\hline Mixed forests & 0.03 & 0.07 \\
\hline Transitional woodland-shrubs & 0.88 & 1.79 \\
\hline In total & $\mathbf{4 9 . 1 2}$ & $\mathbf{1 0 0} \%$ \\
\hline
\end{tabular}

Data obtained from Corine database indicate the highest presentation of agricultural land in the settlement of Vrčin, with a total share of more then threequarters. According to this methodology, such areas are divided into 4 different classes, which in their names also contain some other types of vegetation (e.g. "Land principally occupied by agriculture, with significant areas of natural vegetation"), which even without further analysis indicates a high level of this method generalization. Agricultural areas are followed by areas without vegetation (labeled as "discontinuous urban fabric"). Urban areas are present in the central, southern and western part of the settlement. Then follows the deciduous forests in the northeastern, western and southwestern and shrublands in the northern and also southwestern part of the settlement.

In order to examine the changes ${ }^{6}$ that occurred in the vegetation cover of Vrčin settlement in the period of 12 years, the map of vegetation was made based on the data from the Corine $2012^{7}$ database (Figure 3-9), and their areas and shares in the total area of settlement are shown in Table 3.

6 The general problem for scientific research is the lack of quality data about the types and extent of land use changes, and with even less systematic data of the causes and consequences of these changes (Stojković, 2017).

7 Copernicus (2012) 
Comparative Analysis of NDVI Index and Different Satellite Images Classifications in Determination the Vegetation Inventory of Vrčin Settlement

Table 3. Types of vegetation according to CORINE 2012 database

\begin{tabular}{|c|r|r|}
\hline Land use and types of vegetation & Surface area $\mathbf{( k m}^{\mathbf{2}}$ & Share (\%) \\
\hline Discontinuous urban fabric & 6.57 & 13.38 \\
\hline Industrial or commercial units & 0.01 & 0.02 \\
\hline Non-irrigated arable land & 2.43 & 4.96 \\
\hline Fruit trees and berry plantations & 1.09 & 2.22 \\
\hline Pastures & 0.12 & 0.25 \\
\hline Complex cultivation patterns & 12.74 & 25.93 \\
\hline Land principally occupied by agriculture, & 20.04 & 40.79 \\
\hline with significant areas of natural vegetation & 5.20 & 10.59 \\
\hline Broad-leaved forests & 0.03 & 0.07 \\
\hline Mixed forests & 0.88 & 1.79 \\
\hline Transitional woodland-shrubs & $\mathbf{4 9 . 1 2}$ & $\mathbf{1 0 0} \%$ \\
\hline
\end{tabular}

Changes over a period of 12 years relate primarily to the smaller share of built-up areas than before, which can be seen in the southern part of the settlement. Since there was no demolition of buildings in the settlement during this period, this reduction can be explained as a correction of the mistake of the original 2000 classification. On the other hand, in the western part of the settlement, the share of built-up areas is growing, at the places of different agricultural surfaces. The only new class in this area in comparison to 2000 is "Industrial or commercial units", which do not exist in the area covered by this class. The reason for this is that the selected area is located next to the border of the settlement of Ripanj, where objects corresponding to the mentioned class exists, so it is highly probable that the classification involved a larger space than it should, which once again confirms the generalization in Corina database. There are less agricultural areas in total, but they are slightly different in terms of classes, and the most significant share increase is for fruit plantations. The share of forest is higher by almost $50 \%$, which is certainly an improvement compared to the previous data from 2000, but still insufficient. The conclusion is that the Corine Land Survey Database has become much better and more accurate with the latest edition of 2012. However, its generalization, the neglect of small surfaces ${ }^{8}$ is still present, which leads to that, for example, built-up areas include a smaller area with forests or agricultural land. Corine solves this by denoting such class as "Discontinuous urban area", thereby highlighting the inhomogeneity of the surface.

8 The fact that CLC does not go below the range of 4 to 5 ha is proved to be unfavorable for Serbia, where privately owned parcels usually cover much smaller areas (Jovanović, et al., 2018) 


\section{GlobeLand30}

The instructions (GIS Geography, n.d.) for using the data from the GlobeLand30 database indicate that one of the sources for its creation is the Corine Land Cover, which justifies the absolute overlap of certain areas in these two databases. The difference is that GlobeLand $30^{\circ}$ has less land use classes since it uses data from multiple sources, so the corresponding classes of land use from the Corine database are merged into the same class (Table 4; Figure 3-11).

Table 4. Types of vegetation according to the GlobeLand30 database

\begin{tabular}{|c|r|r|}
\hline Land use and types of vegetation & Surface area $\mathbf{( k m}^{\mathbf{2}}$ & Share $\mathbf{( \% )}$ \\
\hline Artificial surfaces & 7.45 & 15.16 \\
\hline Cultivated land & 37.56 & 76.47 \\
\hline Forests & 4.11 & 8.37 \\
\hline In total & $\mathbf{4 9 . 1 2}$ & $\mathbf{1 0 0} \%$ \\
\hline
\end{tabular}

\section{GlobCover}

In the GlobCover database, in the area covered by this paper, a large part of the settlement area (14.1\%) is marked as "Urban areas" and they are represented in the central, southern and lesser in the western part of the settlement. Shrub areas are marked in the northern part of the settlement in a small percentage $(0.3 \%)$. The forests are evenly distributed along the periphery of the settlement $(16.8 \%)$, which are almost in any case followed by meadows and pastures, which are significantly less $(6.3 \%)$, while all other areas that dominate this database in the area of the settlement Vrčin and distributed in the entire analyzed area, labeled as agricultural land (62.5\%) (Table 5).

Table 5. Types of vegetation according to the GlobCover database

\begin{tabular}{|c|c|c|}
\hline Land use and types of vegetation & Surface area $\left.\mathbf{( k m}^{\mathbf{2}}\right)$ & Share $\mathbf{( \% )}$ \\
\hline Cropland rainfed & 30.55 & 62.20 \\
\hline Herbaceous cover & 0.54 & 1.11 \\
\hline Tree or shrub cover & 0.14 & 0.29 \\
\hline Mosaic cropland $>50 \% /$ natural vegetation $<50 \%$ & 0.15 & 0.31 \\
\hline Mosaic natural vegetation $>50 \% /$ cropland $<50 \%$ & 2.58 & 5.24 \\
\hline Tree cover broadleaved deciduous & 8.11 & 16.52 \\
\hline Mosaic tree and shrub / herbaceous cover & 0.14 & 0.28 \\
\hline Urban areas & 6.90 & 14.05 \\
\hline In total & $\mathbf{4 9 . 1 2}$ & $\mathbf{1 0 0} \%$ \\
\hline \hline
\end{tabular}

$9 \quad$ NGCC (2010) 
Statistically, GlobCover ${ }^{10}$ looks more precisely than Corina, and the surfaces are divided into a large number of classes, some of which are unclearly divided, as is the case with Corina. For example " Mosaic cropland $>50 \%$ / natural vegetation $<50 \%$ " and "Mosaic natural vegetation $>50 \%$ / cropland $<50 \%$ ". Therefore, in both of these classes cropland and natural vegetation are also present, it is only a question of what land use is more dominant. However, the resolution is very large and one look at the map (Figure 3-13) annuls all statistical indicators.

\section{MODIS - Global Land Cover Climatology}

A high level of generalization of MODIS database is clearly seen from the example for the settlement Vrčin (Figure 3-15), whose entire surface is presented as agricultural, partly homogeneous, and partly in the presence of vegetation (Table 6).

Table 6. Types of vegetation according to MODIS database

\begin{tabular}{|c|r|r|}
\hline Land use and types of vegetation & Surface area $\left.\mathbf{( k m}^{\mathbf{2}}\right)$ & Share (\%) \\
\hline Croplands & 17.56 & 35.74 \\
\hline Croplands / Natural Vegetation Mosaic & 31.57 & 64.26 \\
\hline In total & $\mathbf{4 9 . 1 2}$ & $\mathbf{1 0 0 \%}$ \\
\hline
\end{tabular}

\section{USGS - Global Land Cover Characterization (GLCC)}

The improvement of GLCC compared to the previously presented database is that besides agricultural land there is a smaller share of forests (Table 7). However, as the resolution of the pixels is even higher $(1 \mathrm{~km})$, the quality of the data also is not satisfactory, which is best seen on the map (Figure 3-17).

Table 7. Types of vegetation according to the GLCC database

\begin{tabular}{|c|r|r|}
\hline Land use and types of vegetation & Surface area $\left.\mathbf{( k m}^{\mathbf{2}}\right)$ & Share (\%) \\
\hline Cultivated and managed areas & 46.12 & 93.89 \\
\hline Tree Cover, broadleaved, deciduous, closed & 3.00 & 6.11 \\
\hline In total & $\mathbf{4 9 . 1 2}$ & $\mathbf{1 0 0} \%$ \\
\hline
\end{tabular}

\section{Global Land Survey (GLS)}

In resolution of 30 meters, GLS classification of land use for 2010 is one of the best available. It distinguishes areas with vegetation, surfaces without vegetation and surface water. Vegetation data are given only percentally (the share of forests on the selected area), without mentioning the type of vegetation, so this is the biggest disadvantage of this database.

\footnotetext{
10 $\operatorname{ESA}(2010 b)$
} 
In the area that includes the settlement of Vrčin, according to GLS ${ }^{11}$, the forests are more present along the periphery of the settlements, and going towards its center the percentage of vegetation is decreasing, which is logical, since the objects and the roads are mostly built in the middle of the settlement, and the area dominated by the highway E75 can be clearly seen (Figure 3-19). The table shows the corresponding data on the representation of forests in the settlement of Vrčin through 5 classes in relation to the percentage share of forests on a selected surface (Table 8).

Table 8. Types of vegetation according to the Global Land Survey database

\begin{tabular}{|c|r|r|}
\hline Land use and types of vegetation & Surface area $\left.\mathbf{( k m}^{\mathbf{2}}\right)$ & \multicolumn{1}{|c|}{ Share (\%) } \\
\hline $0 \%$ forest & 26.24 & 53.42 \\
\hline $0 \%-25 \%$ forest & 6.18 & 12.58 \\
\hline $25 \%-50 \%$ forest & 4.85 & 9.86 \\
\hline $50 \%-75 \%$ forest & 3.75 & 7.63 \\
\hline $75 \%-100 \%$ forest & 8.11 & 16.51 \\
\hline In total & $\mathbf{4 9 . 1 2}$ & $\mathbf{1 0 0} \%$ \\
\hline
\end{tabular}

Synthesis of results and comparison methodologies

The diversity of all methodologies presented in this paper is evident from the preceding text, and the mismatch of their results can be particularly noticeable if it is graphically displayed (Figure 2).

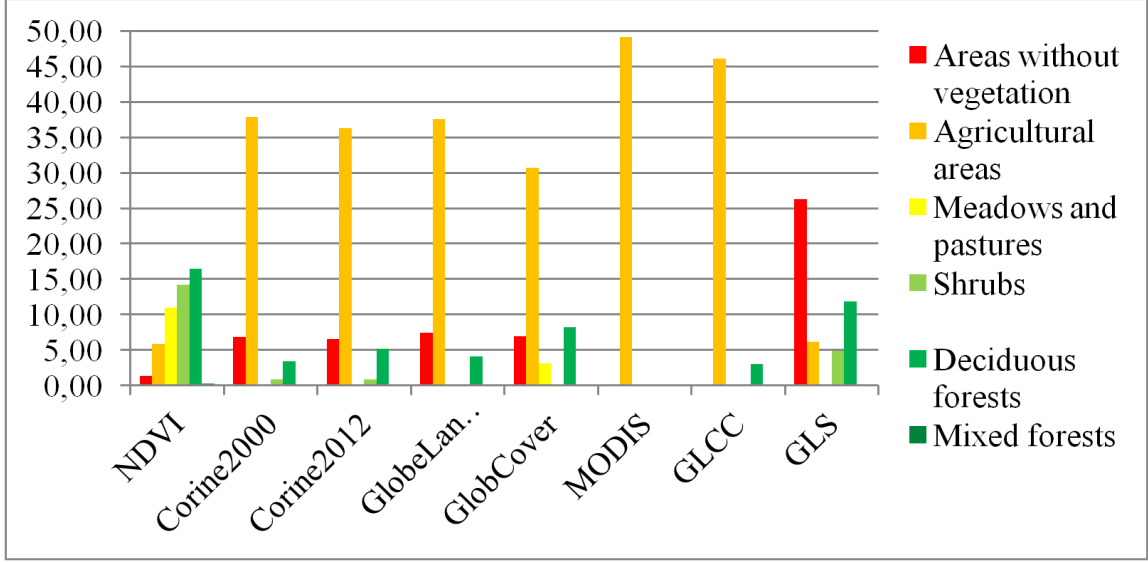

Figure 2. Comparative overview of the share of vegetation categories in the total area of the settlement Vrčin according to selected databases

11 University of Maryland (n.d.) 
From the presented chart it is clear that in all used databases dominate the agricultural areas, except for the Global Land Survey. In most of these classifications, the agricultural areas are labeled to contain other types of vegetation, but it is not specified where and to what extent, so the vegetation contained within such surfaces can not be seen or compared with the data obtained in this paper. This result is due to the fact that during the creation of the Corine database only areas of more than 4 ha were considered, which can not result in accuracy for the conditions in our country, since there is an exceptional fragmentation of the land properties and the differentiation of the cultivated cultures on them. Another problem that arises is the large share of agricultural land that has not been processed for a longer or shorter period, and during the creation of the NDVI at their places were grasslands and shrub vegetation. The large area coverage in the Corine database ignores the fact that in this case it is a rural settlement, where the most common agricultural production is on the garden, so these areas are included in the urban area and therefore are not shown in its graphic or quantitative data.

In the software, the comparation of the surfaces of the included vegetation types according to the NDVI and other classifications individually, showing the overlap of the surfaces of the same vegetation types and the land use, and then the data on such surfaces are presented in a table with the total areas of vegetation classes that are standardized to classes obtained by the NDVI, for the needs of mutually analysis, so that all these methodologies are mutually comparable. Then, it is presented the index of deviation of the total area of a certain vegetation class from the equivalent class obtained by the analysis of the satellite image by the NDVI, as well as the share of overlapping of vegetation class in relation to NDVI.

Table 9. Overlapping vegetation classes: NDVI and Corine2000

\begin{tabular}{|c|c|c|c|c|}
\hline \multirow[b]{2}{*}{ Type of vegetation } & \multirow{2}{*}{$\begin{array}{l}\text { Surface area } \\
\left(\mathrm{km}^{2}\right)\end{array}$} & \multirow{2}{*}{$\begin{array}{c}\text { Deviation } \\
\text { index from } \\
\text { NDVI }\end{array}$} & \multicolumn{2}{|c|}{ Overlap with NDVI } \\
\hline & & & $\begin{array}{l}\text { Surface area } \\
\qquad\left(\mathbf{k m}^{2}\right)\end{array}$ & $\begin{array}{c}\% \\
\text { overlap }\end{array}$ \\
\hline Areas without vegetation & 6.81 & 5.09 & 0.48 & 7.00 \\
\hline Agricultural areas & 37.91 & 6.48 & 3.75 & 9.90 \\
\hline Meadows and pastures & 0.12 & 0.01 & 0.001 & 0.92 \\
\hline Shrubs & 0.88 & 0.06 & 0.16 & 17.62 \\
\hline Deciduous forests & 3.36 & 0.20 & 2.93 & 87.28 \\
\hline Mixed forests & 0.03 & 0.11 & 0.00 & 0.00 \\
\hline In total & 49.12 & - & 7.32 & 14.89 \\
\hline
\end{tabular}


Table 10. Overlapping vegetation classes: NDVI and Corine 2012

\begin{tabular}{|c|r|r|r|r|}
\hline \multirow{2}{*}{ Type of vegetation } & \multirow{2}{*}{$\begin{array}{c}\text { Surface area } \\
\mathbf{( k m}^{\mathbf{2}} \mathbf{n}\end{array}$} & $\begin{array}{c}\text { Deviation } \\
\text { index from } \\
\text { NDVI }\end{array}$ & $\begin{array}{c}\text { Surface area } \\
\mathbf{( k m}^{\mathbf{2}}\end{array}$ & $\begin{array}{c}\text { Overlap with NDVI } \\
\text { overlap }\end{array}$ \\
\hline Areas without vegetation & 6.58 & 4.92 & 0.51 & 7.70 \\
\hline Agricultural areas & 36.30 & 6.20 & 3.80 & 10.46 \\
\hline Meadows and pastures & 0.12 & 0.01 & 0.001 & 0.93 \\
\hline Shrubs & 0.88 & 0.06 & 0.16 & 17.63 \\
\hline Deciduous forests & 5.20 & 0.32 & 4.46 & 85.74 \\
\hline Mixed forests & 0.03 & 0.11 & 0.00 & 0.00 \\
\hline In total & $\mathbf{4 9 . 1 2}$ & - & $\mathbf{8 . 9 2}$ & $\mathbf{1 8 . 1 6}$ \\
\hline
\end{tabular}

Similar results have been obtained for both Corine classifications (Tables 9 and 10; Figures 3-8 and 3-10), but the overlap percentage is increased by more than $3 \%$. The overlap percentage is the highest for the deciduous forest class, and the lowest for meadows and pastures, if we ignore the mixed forests, which have a very small share in both classifications and which do not have any overlapping of data obtained from these two methodologies.

The total deviation index also shows the highest accuracy in deciduous forests, which is about 4 (Corine2000), i.e. 3 times less (Corine2012) than the NDVI, while the accuracy of other categories is far below this level.

Table 11. Overlapping vegetation classes: NDVI and GlobeLand30

\begin{tabular}{|c|c|c|c|c|}
\hline \multirow[b]{2}{*}{ Type of vegetation } & \multirow{2}{*}{$\begin{array}{c}\text { Surface area } \\
\left(\mathbf{k m}^{2}\right)\end{array}$} & \multirow{2}{*}{$\begin{array}{l}\text { Deviation index } \\
\text { from NDVI }\end{array}$} & \multicolumn{2}{|c|}{ Overlap with NDVI } \\
\hline & & & $\begin{array}{c}\text { Surface area } \\
\left(\mathbf{k m}^{2}\right)\end{array}$ & $\begin{array}{c}\% \\
\text { overlap }\end{array}$ \\
\hline $\begin{array}{l}\text { Areas without } \\
\text { vegetation }\end{array}$ & 7.45 & 5.57 & 0.62 & 8.35 \\
\hline Agricultural areas & 37.56 & 6.42 & 3.63 & 9.65 \\
\hline Deciduous forests & 4.11 & 0.25 & 3.33 & 81.02 \\
\hline In total & 49.12 & - & 7.58 & 15.43 \\
\hline
\end{tabular}

The GlobeLand30 database and the NDVI methodology overlap also shows the highest intersection precision, as well as the deviation index for deciduous forests (Table 11, Figure 3-12). As Corine is the main data source for the European part of this classification, it is clear why the results obtained are quite similar to this methodology. 
Comparative Analysis of NDVI Index and Different Satellite Images Classifications in Determination the Vegetation Inventory of Vrčin Settlement

Table 12. Overlapping vegetation classes: NDVI and GlobCover

\begin{tabular}{|c|c|c|c|c|}
\hline \multirow[b]{2}{*}{ Type of vegetation } & \multirow{2}{*}{$\begin{array}{c}\text { Surface area } \\
\qquad\left(\mathrm{km}^{2}\right)\end{array}$} & \multirow{2}{*}{$\begin{array}{l}\text { Deviation index } \\
\text { from NDVI }\end{array}$} & \multicolumn{2}{|c|}{ Overlap with NDVI } \\
\hline & & & $\begin{array}{c}\text { Surface area } \\
\left(\mathbf{k m}^{2}\right)\end{array}$ & $\begin{array}{c}\% \\
\text { overlap }\end{array}$ \\
\hline Areas without vegetation & 6.90 & 5.16 & 0.48 & 6.99 \\
\hline Agricultural areas & 30.71 & 5.25 & 3.54 & 11.53 \\
\hline Meadows and pastures & 3.12 & 0.28 & 0.42 & 13.58 \\
\hline Shrubs & 0.14 & 0.01 & 0.05 & 35.66 \\
\hline Deciduous forests & 8.25 & 0.50 & 5.10 & 61.83 \\
\hline In total & 49.12 & - & 9.60 & 19.54 \\
\hline
\end{tabular}

Another classification that gave very similar results as Corine and GlobeLand30 is GlobCover, although this time the percentage of overlapping forests is smaller, but therefore the deviation index is also less than 0.5 (means that the forest are only two times less), which is an excellent result compared to other databases. The overlapping percentage is also good for the shrub areas, however, the deviation index shows a significant inconsistency in the total area of this vegetation class in relation to NDVI (Table 12, Figure 3-14).

Table 13. Overlapping vegetation classes: NDVI and MODIS

\begin{tabular}{|c|c|c|c|c|}
\hline \multirow[b]{2}{*}{ Type of vegetation } & \multirow{2}{*}{$\begin{array}{c}\text { Surface area } \\
\left(\mathbf{k m}^{2}\right)\end{array}$} & \multirow{2}{*}{$\begin{array}{l}\text { Deviation index } \\
\text { from NDVI }\end{array}$} & \multicolumn{2}{|c|}{ Overlap with NDVI } \\
\hline & & & $\begin{array}{l}\text { Surface area } \\
\left(\mathbf{k m}^{2}\right)\end{array}$ & $\begin{array}{c}\% \\
\text { overlap }\end{array}$ \\
\hline Agricultural areas & 49.12 & 8.40 & 5.98 & 12.16 \\
\hline In total & 49.12 & - & 5.98 & 12.16 \\
\hline
\end{tabular}

The complete contradiction with the previously stated results is MODIS database, which represents the territory of Vrčin settlement exclusively for agricultural areas, and it is clear that both indicators of compatibility with the NDVI methodology are very unfavorable (Table 13, Figure 3-16).

Table 14. Overlapping vegetation classes: NDVI and Global Land Cover Characterization

\begin{tabular}{|c|r|r|r|r|}
\hline & \multirow{2}{*}{ Type of vegetation } & \multirow{2}{*}{$\begin{array}{c}\text { Surface area } \\
\mathbf{( k m}^{2} \mathbf{)}\end{array}$} & $\begin{array}{c}\text { Deviation } \\
\text { index from } \\
\text { NDVI }\end{array}$ & \multicolumn{2}{|c|}{\begin{tabular}{c} 
Overlap with NDVI \\
\cline { 4 - 5 }
\end{tabular}} & & & $\begin{array}{c}\text { Surface area } \\
\mathbf{( k m}^{2} \mathbf{)}\end{array}$ & $\begin{array}{c}\mathbf{\%} \\
\text { overlap }\end{array}$ \\
\hline Agricultural areas & 46.12 & 7.88 & 5.70 & 12.35 \\
\hline Deciduous forests & 3.00 & 0.18 & 1.22 & 40.70 \\
\hline In total & $\mathbf{4 9 . 1 2}$ & - & $\mathbf{6 . 9 2}$ & $\mathbf{1 4 . 0 8}$ \\
\hline
\end{tabular}


Slightly different results were obtained for the GLCC classification, which, in addition to the extremely dominant agricultural areas, has a small share of deciduous forests, for which only the percentage of overlaps is conditionally favorable (Table 14, Figure 3-18).

Table 15. Overlapping vegetation classes: NDVI and Global Land Survey

\begin{tabular}{|c|c|c|c|c|}
\hline \multirow[b]{2}{*}{ Type of vegetation } & \multirow{2}{*}{$\begin{array}{c}\text { Surface area } \\
\left(\mathrm{km}^{2}\right)\end{array}$} & \multirow{2}{*}{$\begin{array}{c}\text { Deviation } \\
\text { index from } \\
\text { NDVI }\end{array}$} & \multicolumn{2}{|c|}{ Overlap with NDVI } \\
\hline & & & $\begin{array}{c}\text { Surface area } \\
\left(\mathbf{k m}^{2}\right)\end{array}$ & $\begin{array}{c}\% \\
\text { overlap }\end{array}$ \\
\hline Areas without vegetation & 26.24 & 19.61 & 1.23 & 4.68 \\
\hline Agricultural areas & 6.18 & 1.06 & 0.58 & 9.45 \\
\hline Shrubs & 4.85 & 0.34 & 3.18 & 65.72 \\
\hline Deciduous forests & 11.86 & 0.72 & 10.14 & 85.51 \\
\hline In total & 49.12 & - & 15.13 & 30.81 \\
\hline
\end{tabular}

The final methodology (Global Land Survey) has given the best results compared to the NDVI, but this comparison must be taken conditionally, since GLS only gives data on the percentage of forests on a selected surface, and on the basis of this data, it is concluded that the corresponding surface belongs to the type of vegetation (e.g. all areas that are said to have more than $50 \%$ of the area under the trees are seen as forests). This has led to quite satisfactory results, especially when it comes to the deviation index for deciduous forests, and even more for agricultural land, which is almost ideal. The overlap percentage also shows good results, first of all in terms of forests and shrub areas (Table 15, Figure 3-20).

\section{Conclusion}

In addition to numerous advantages and innovations without which people can not imagine life on Earth, the modern age also brings great disadvantages, and one of the biggest is the disturbance of environment quality. In order to escalate from an increasing degradation at one point to the progradation of the environment, it is necessary to establish a quality and efficient monitoring system. This way, modern technologies would not only affect the degradation of the environment, but would be used for its preservation and improvement.

Using these methods by comparative observation of false and true color composites, as well as the NDVI and their comparison with various classifications of vegetative inventory, it can be concluded that neither one publicly available database is a good solution for the analysis of vegetation in the territory of 
Serbia, in particular its central part where the fragmentation of property is very pronounced, and especially the problem occurs when analyzing a smaller area, as in case with the settlement of Vrčin, where much more detailed data on surfaces is needed, and the minimum individual surface of a particular vegetation class in most of the above classifications exceeds the average size of the property in Serbia. Otherwise, the dominant catagories of vegetation on a certain surface will "swallow" other types and such data are then only partially accurate, which is absolutely unacceptable for any serious research.

On the contrary, the use of teledetection leads to significantly more accurate data, which on the one hand depends on the researcher's expertise, and on the other hand on the quality (primarily the resolution) of the satellite image being processed and the conditions in which the image is created. With the correct application of numerous features of different softwares, it is possible to obtain a variety of vegetation data, such as those about different types of vegetation, the condition of individual species, and at the same time provide the possibility of tracking changes in both categories for unlimited time and space. The data thus obtained can be used to correct condition of certain vegetation types, both for quality and quantity, as well as for preventive protection of vegetation.

No research methodology is not and can not be ideal, and therefore the classification of the satellite image via the NDVI can not give absolutely accurate results. However, considering the amount of time and resources invested, as well as the quality of the obtained results for the analyzed areas which can be extremely large, the methodology presented in this paper is currently the best choice for the purposes of determining the vegetation inventory of the appropriate area which geographic information systems can offer.

\section{Acknowledgement}

The paper presents the result of research on project no. 176017, financed by the Ministry of Education, Science and Technological Development of the Republic of Serbia. 


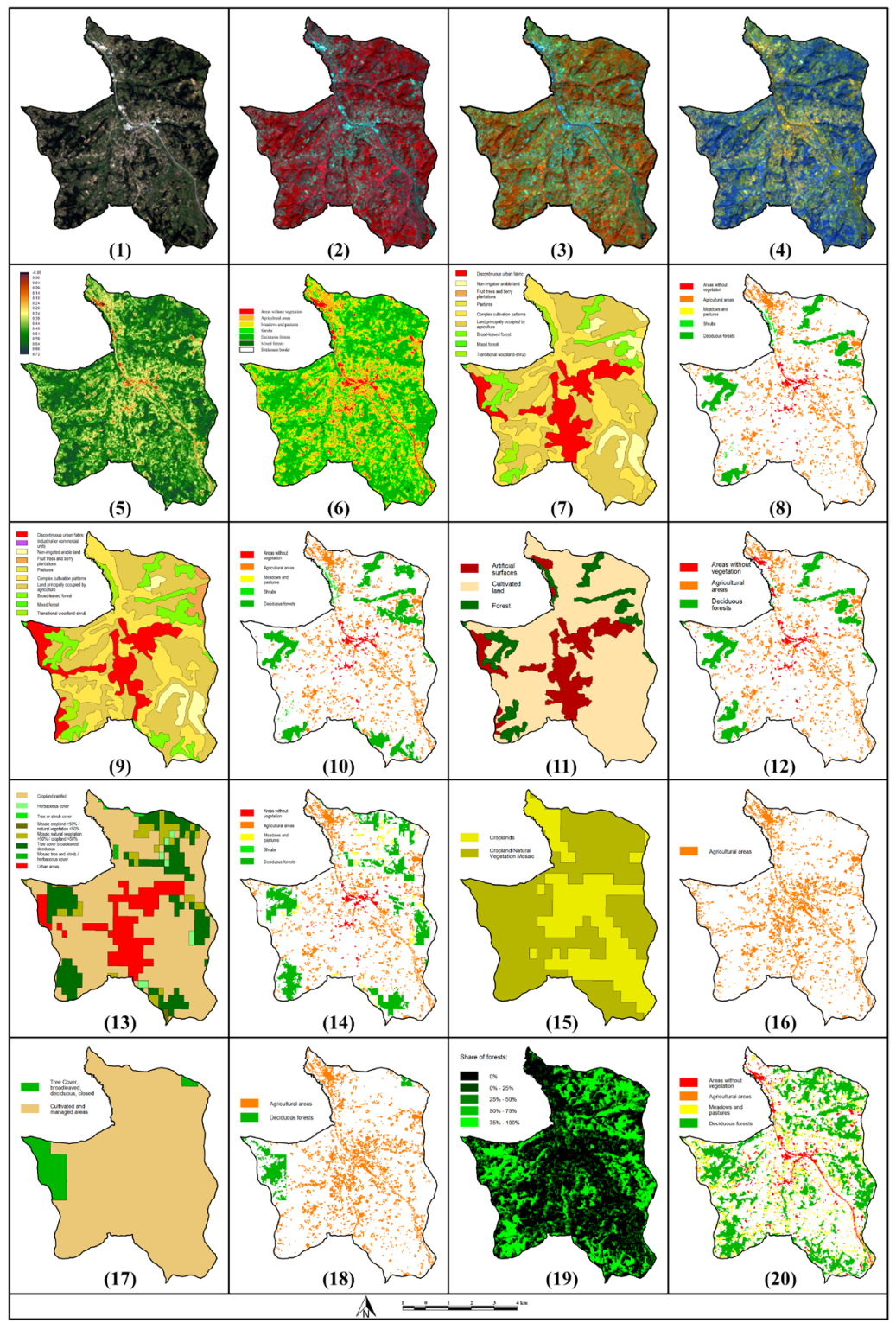

Figure 3. (1) True color composite - channels 321; (2) Fake color composite - 432;

(3) Fake color composite - 453; (4) Fake color composite - 754; (5) NDVI of the Vrčin settlement; (6) Classified NDVI of the Vrčin settlement; (7) Corine2000; (8) Overlap: NDVI and

Corine2000; (9) Corine2012; (10) Overlap: NDVI and Corine2012; (11) GlobaLand30;

(12) Overlap: NDVI and GlobaLand30; (13) GlobeCover; (14) Overlap: NDVI and GlobeCover;

(15) MODIS; (16) Overlap: NDVI and MODIS; (17) Global Land Cover Characterization;

(18) Overlap: NDVI and GLCC; (19) Global Land Survey; (20) Overlap: NDVI and GLS 


\section{References}

Бадњаревић, И., Говедарица, М., Јовановић, Д., Пајић, В., \& Ристић, А. (2012). Примена геоинформационих технологија у процесу детектовања нагиба површине терена Фрушке горе са освртом на развој падинских процеса. Нови Сад: Универзитет у Новом Саду - Факултет техничких наука.

Борисов, М., Бранковић, Р., \& Дробњак, С. (2009). Моделовање процеса над топографским подацима. Гласник српског географског друштва, 89(3), 207-218.

Љешевић, М. (2005). Животна средина - теорија и методологија истраживања. Београд: Универзитет у Београду - Географски факултет.

Милановић, М., \& Љешевић, М. (2009). Теледетекционе методе истраживаюа животне средине. Београд: Универзитет у Београду - Географски факултет.

Милинчић, М. (2013). Неки аспекти утицаја пољопривреде на животну средину. Зборник радова - Географски фокултет Универзитета у Београду, 61, 31-46.

Несторов, И., \& Протић, Д. (2009). CORINE картирање земьишног покривача у Србији. Београд: Грађевинска књига.

Ракић, У. (2006). Одржавање равнотеже између становништва и ресурса. Зборник радова - Географоски факултет Универзитета у Београду, 54, 115-126.

Смиљанић, С., \& Ђурђић, С. (2006). Примена ГИС-а у вредновању природних потенцијала општине Ражањ за потребе пољопривреде. Гласник сриског географрског друштва, 86(2), 161-165.

Томић, М. (2014). The use of methods of remote sensing and GIS applications in monitoring water quality on the example of the mining basin Kolubara, Lazarevac. Београд: Геонаука.

Упоредни преглед броја становника 1948-2011. У Попис становништва, домаћинстава и станова у 2011. години (св. 20). Београд: Републички завод за статистику.

Bedard, F., Crump, S., \& Gaudreau, J. (2006). A comparison between Terra MODIS and NOAA AVHRR NDVI satellite image composites for the monitoring of natural grassland conditions in Alberta, Canada. Canadian Journal of Remote Sensing, 32(1), 44-50.

Belić, I., Radosavljević, Lj., Milinčič, M., \& Šabić, D. (2012). Laser System for Remote Sensing Monitoring of Air Pollution and Quality Control of the Atmosphere. Thermal Science, 16(4), 1201-1211

Broxton, P.D., Zeng, X., Sulla-Menashe, D., \& Troch, P.A. (2014). A Global Land Cover Climatology Using MODIS Data. J. Appl. Meteor. Climatol., 53, 1593 - 1605. doi: http://dx.doi.org/10.1175/JAMC-D-13-0270.1

Copernicus. (2000). Corine Land Cover 2000. Retrieved from https://land. copernicus.eu/pan-european/corine-land-cover/clc-2000?tab=download 
Copernicus. (2012). Corine Land Cover 2012. Retrieved from https://land. copernicus.eu/pan-european/corine-land-cover/clc-2012?tab=download

Đurđić, S., Stojković, S., \& Šabić D. (2011). Nature conservation in urban conditions: A case study from Belgrade, Serbia. Maejo International Journal of Science and Technology, 5(01), 129-145.

European Space Agency - ESA. (2010a). ESA Climate Change Initiative. Retrieved from https://www.esa-landcover-cci.org/

European Space Agency - ESA. (2010b). GlobCover. Retrieved from http://due. esrin.esa.int/page_globcover.php

GIS Geography. (n.d.). 9 Free Global Land Cover / Land Use Data Sets. Retrieved from https:/ / gisgeography.com/free-global-land-cover-land-use-data/

Guo, X., Zhang, H., Wu, Z., Zhao, J., \& Zhang, Z. (2017). Comparison and Evaluation of Annual NDVI Time Series in China Derived from the NOAA AVHRR LTDR and Terra MODIS MOD13C1 Products. Sensors, 17(6), 1298.

Jovanović, M.M., \& Milanović, M.M. (2015). Normalized Difference Vegetation Index (NDVI) as the Basis for Local Forest Management. Example of the Municipality of Topola, Serbia. Polish Journal of Environmental Studies, 24(2), 529-535.

Jovanović, M.M., Milanović, M.M., \& Zorn, M. (2018). The use of NDVI and CORINE Land Cover databases for forest management in Serbia. Acta geographica Slovenica, 58(1), 109-123.

Jun, C, Ban, Y., \& Li, S. (2014). Nature 514, 434, China: Open access to Earth land-cover map. http:/ / www.nature.com/nature/journal/v514/n7523/full/514434c.html

Kovalskyy, V., Roy, P. D., Zhang, Y. X., Ju, J. (2012). The suitability of multi-temporal web-enabled Landsat data NDVI for phenological monitoring - a comparison with flux tower and MODIS NDVI. Remote Sensing Letters, 3(4), 325-334.

Loveland, T.R., Reed, B.C., Brown, J.F., Ohlen, D.O., Zhu, J, Yang, L., \& Merchant, J.W. (2000). Development of a Global Land Cover Characteristics Database and IGBP DISCover from 1-km. AVHRR Data:International Journal of Remote Sensing, v. 21, no. $6 / 7$, p. 1,303-1,330.

Ma, X., Tong, X., Liu, S., Luo, X., Xie, H., \& Li, C. (2017). Optimized Sample Selection in SVM Classification by Combining with DMSP-OLS, Landsat NDVI and GlobeLand30 Products for Extracting Urban Built-Up Areas. Remote Sensing, 9, 236.

Milincic, M., Vujadinović, S., Ćurčić, N., \& Šabić, D. (2013). Effects of Geoecological Factors on Vegetation of the Gruža Basin. Archives of Biological Sciences, 65 (1), 121-131.

National Aeronautics and Space Administration - NASA \& U.S. Geological Survey - USGS. (n.d.). Global Land Surveys (GLS). Retrieved from https:/ / landsat.usgs. gov/global-land-surveys-gls

National Aeronautics and Space Administration - NASA \& U.S. Geological Survey - USGS. (2011). LT51860292011232MOR00. Retrieved from http:// earthexplorer.usgs. gov/ 
National Geomatics Center of China - NGCC. (2014). 30-meter Global Land Cover Dataset - Product Description.

National Geomatics Center of China - NGCC. (2010). GlobeLand30. Retrieved from http:// www.globallandcover.com/GLC30Download/index.aspx

Peng, D. L., Liu, L. Y., Zhang, B., \& Shen, Q. (2011). Comparisons of FPAR Derived from GIMMS AVHRR NDVI and MODIS Product. In IEEE International Symposium on Geoscience and Remote Sensing IGARSS, Vancouver, Canada, 24-29 July 2011 (pp. 1842-1845). Inst Elect \& Elect Engineers Geosci \& Remote Sensing Soc.

Stojković, S. (2017). GIS Analysis of Land Use Changes - Case Study: the Stara Pazova Municipality, Serbia. Collection of Papers - Faculty of Geography at the University of Belgrade, 65 (1a), 295-306.

Šabić, D., Miljković, O., Vujadinović, S., Milinčić, M., \& Gajić M. (2013). Geoecological Transformation of Wetland into Agricultural Landscape: The Case of Pančevački Rit, Serbia. Journal of Environmental Protection and Ecology, 14(2), 524531.

Šabić, D., Vujadinović, S., Stojković, S., \& Djurdjić, S. (2018). Urban Development Consequences on the Wetland Ecosystems Transformations-Case Study: Pančevački Rit, Serbia. Contemporary Problems of Ecology, 11(2), 227-238.

University of Maryland. (n.d.). Global Forest Change. Retrieved from http:// earthenginepartners.appspot.com/science-2013-global-forest

U.S. Geological Survey's - USGS. (n.d.a). Global Land Cover Characteristics Data Base Version 2.0. Retrieved from https:/ /lta.cr.usgs.gov/glcc/globdoc2_0

U.S. Geological Survey's - USGS. (n.d.b). Global Land Cover Characterization. Retrieved from https:/ / earthexplorer.usgs.gov/

USGS Land Cover Institute - LCI (2010). 0.5 km MODIS-based Global Land Cover Climatology. Retrieved from https://landcover.usgs.gov/global_climatology. php

Wardlow, D.B., \& Egbert, L.S. (2010). A comparison of MODIS 250-m EVI and NDVI data for crop mapping: a case study for southwest Kansas. International Journal of Remote Sensing, 31(3), 805-830.

Wulder, M.A., \& Coops, N.C. (2014) Nature 513, Satellites: Make Earth observations open access, 30-31. https://www.nature.com/news/satellites-make-earthobservations-open-access-1.15804

Yague, J., \& Garcia, P. (2004). Approaching corine land cover over Castilla and Leon (central Spain) with a multitemporal NOAA-AVHRR NDVI MVC series. In Series in Remote Sensing, Volume: 3, Ispra, Italy, 16-18 July 2003 (pp. 314-321). Univ Trento, Dept Informat \& Commun Technologies; IEEE Geosci \& Remote Sensing Soc.

Zhang, W., Liao, A., Peng, S., Zheng, X., \& Li., M. (2015). Check and modification of GlobeLand30 with MODIS NDVI. In Proceedings of SPIE 9675, 8 October 2015. AOPC 2015: Image Processing and Analysis, 967500 